\title{
The circular economy and the Green Jobs creation
}

\author{
Adam Sulich $^{1}$ (D) - Letycja Sołoducho-Pelc ${ }^{1}$
}

Received: 3 June 2021 / Accepted: 11 September 2021 / Published online: 3 October 2021

(C) The Author(s) 2021

\begin{abstract}
The circular economy (CE) is a proposal for a new, more sustainable, and durable economy model. As a consequence, this proenvironmental economic model induces visible changes in the labor market which are Green Jobs (GJs). This paper is focused on the creation of Green Jobs in the CE. The GJs are most visible in the environmental goods and services sector (EGSS). This study aims to investigate EGSS among 28 European Union countries in the years 2009-2019. The adopted method was literature research complemented by the statistical analysis of secondary data from Eurostat in the linear regression method. Then, some Sustainable Development Goals (SDGs) and their measure were used as main indicators reflecting changes in the labor market. Results are presented as a model indicating which of the SDGs can support CE and enhance a number of the Green Jobs. Presented results contribute to the science because combine factors influencing GJs creation in EGSS, in a CE perspective. This study underlines a lack of uniform methods for measuring and forecasting the effects of Green Jobs creation and indicates future research directions.
\end{abstract}

Keywords Green Jobs · Sustainable development · Environmental goods and services sector · Sustainable Development Goals

\section{Introduction}

The transition from the linear economy to the circular economy (CE) is a process observed both in theory and practice (Ferasso et al. 2020; Gottinger et al. 2020; de Oliveira et al. 2021). The CE can be summarized as a paradigm shift aimed at preventing the depletion of resources (Barreiro-Gen and Lozano 2020) by closing the loops related to energy and materials consumption (Lozano-Lunar et al. 2020; RincónMoreno et al. 2020; O'Connor 2021). This concept can be characterized at the micro- (customers and companies), meso- (economic agents that integrate into symbioses), and macro-levels(from national to regional and city-levels) (Prieto-Sandoval et al. 2018).

Striving for sustainable development (SD) is at the basis of creating a contemporary socio-economic policy of the EU and many countries around the world (Ledoux et al. 2005; Tortorella et al. 2020). This idea of economic development is based on the principle of maintaining synergy and a balance

Responsible Editor: Eyup Dogan

Adam Sulich

adam.sulich@ue.wroc.pl

1 Faculty of Management, Wroclaw University of Economics and Business, Wrocław, Poland between social, economic, and environmental dimensions (Friant et al. 2021). The key role of the SD is crucial in the EU and is visible in multiple documents (Gottinger et al. 2020). Many EU action plans already referred to the SD and emphasized the need to create more sustainable and inclusive growth in Europe (Bartniczak and Raszkowski 2019; Salvioni and Almici 2020). The EU's documents concern not only the transition to the CE but also Green Jobs creation (Friant et al. 2020). The CE is also a solution for the environmental problems that expanded nowadays. The $\mathrm{CE}$ evolved from the linear economy (LE) often called brown economy (BE) which is an economic model based on the extensive combustion of fossil fuels (Briguglio and Brown 2019).

The research gap identified in this paper is the lack of the Green Jobs creation econometric model connections with the CE. Such a model should describe between theoretical assumptions of CE and empirical implications in the emerging GJs using indicators constructed upon the Sustainable Development Goals (SDGs).

This research intends to fulfill indicated gap by investigating the EGSS in EU countries from 2009 to 2019. Therefore, the scope of the paper is focused on the GJs in the context of CE. The GJs are most visible in the environmental goods and services sector (EGSS). What is more, the scientific literature refers to EGSS as the "green sector" (Sinclair-Desgagné 2008). The comprehensive desk research to complement the 
statistical analysis of secondary data from Eurostat for each member state was performed (Eurostat 2020a).

This manuscript is structured as follows. After the research gap and aim of this paper are presented in the introduction, the themes crucial for this research are discussed in the literature review in the second point. The research method is described in the third section, then the results and their discussion are presented. The paper concludes by presenting limitations of the conducted research that were discussed along with the managerial implication and contribution to the knowledge development, and further research directions are addressed.

\section{Literature review}

\section{Circular economy}

The CE concept identifies new opportunities for the simultaneous achievement of environmental benefits and economic growth (Hopkinson et al. 2018; Durán-Romero et al. 2020; van Dam et al. 2020). The idea of CE was based on the observation of natural ecosystems, which are not linear (only energy flows), but resources (materials) circulate (Korhonen et al. 2018; Ilić et al. 2020). Then, all production processes should be devised in such a way to be more like natural closed cycles (Kirchherr et al. 2017).

Pearce et al. (1989) in their report entitled "Blueprint for a green economy" presented and explained how to introduce the SD idea in social and economic processes. The authors of this report have not explicitly defined the $\mathrm{CE}$, underlining their idea that the economy should support the natural environment protection policy. According to Green and McCann (2011), a CE is defined as the concept of an environmentally friendly economy that opens new opportunities (Iacovidou et al. 2021) for creative and innovative activities. In 2020, Hasanli indicated that the CE is the future for the world (Hassanli et al. 2020) based on technological progress. Therefore, the term "green" denotes activities considered essential and beneficial to the environment (Whitmarsh and O'Neill 2010). These views on CE are significantly influenced by the growing interest in the SD (Sauvé et al. 2016). As a result of this increased attention reflected in many scientific studies (Sanguino et al. 2020) and governments' documents, different concepts and derivative definitions were founded (Kirchherr et al. 2017).

The CE is defined as an alternative for the LE (Sulich 2018; Sulich and Zema 2018; Robaina et al. 2020) because CE aims to balance economic activities by closing the loops and creating an ecological system (Boulding 1966; Ruiz-Real et al. 2018; Sanguino et al. 2020). The CE characteristics are often presented in contrast to the linear model of the LE (Table 1). The $\mathrm{CE}$ is considered to be a more sustainable, inclusive, and pro-environmental model of growth and development (Moraga et al. 2019; Sanguino et al. 2020). The LE as a model of economic development has failed because it leads toward the destruction of biodiversity and resources depletion. As a linear system, the LE is based on the false assumption that planet resources are unlimited (Corrêa and Corrêa 2021). The LE caused three main consequences (Baer et al. 2015; Sulich and Zema 2018):

1) Environmental burden resulting from industrialization;

2) Political and bureaucratic inefficiency of the public sector;

3) Increasing income, cultural, racial, and ethnic differences.

The CE is a foundation of the "green civilization" concept, which is characterized by the human and natural environment coexistence, by the harmonious social development, and by the technological innovation in the EGSS (Norgaard 1994). As presented in Figure 1, the CE develops not only qualitatively but also quantitatively - the new processes and jobs are created to cover material cycles (Gottwald 2012; Tomić and Schneider 2020).

The CE is a proposal for a more sustainable and durable economic model (Castillo Castillo and AngelisDimakis2019). What is more, the CE has defined processes that close resources loops (i.e., by recycling) and aims to reduce material losses by incineration and landfill (Hopkinson et al. 2018; O'Connor 2021). The circular economy is a path of economic and social development that relies on investing in the "green recovery." It means a transition from a LE in favor of creating Green Jobs and the shift toward the CE visible in the environmental goods and services sector.

\section{Environmental goods and services sector in European Union}

The definition of the EGSS, which is used in this paper, was published in 2009 in the "EGSS handbook" (Broniewicz and Domańska 2016) in explaining what the environmental goods and services are. In the proposed approach, these goods and services related to environmental protection are distinguished based on the main goal's criterion. The EGSS aim is to protect the environment or manage resources (Moldvay et al. 2013; Broniewicz and Domańska 2016). "Also critical is the producer's awareness of environmental requirements and the creation of environmentally friendly products, the use of products in harmony with the environment, and offering them in markets that take environmental conditions into account" (Eurostat 2015; Broniewicz and Domańska 2016). The definition of EGSS is also stated in Regulation (EU) No. 691/ 2011, when classifying environmental activities based on the objective criterion. These actions area can be divided into environmental protection (EP) and resource nanagement (RM) activities (Steuer et al. 2016; Eurostat 2020b). 
Table 1 Comparison between circular economy versus linear economy features

\begin{tabular}{ll}
\hline Circular economy & Linear economy \\
\hline $\begin{array}{l}\text { Separates the economic growth from the natural } \\
\text { resources use }\end{array}$ & "Unlimited" economic growth \\
Renewable energy sources & Non-renewable energy sources \\
Energy efficiency & Massive consumption of natural resources \\
& (energy and raw materials) \\
Clean production & Greenhouse gas emissions \\
Biodiversity protection & Biodiversity destruction \\
Intergenerational and interregional justice & Creates social inequalities at the global scale \\
Sustainable consumption & Unlimited consumption (overconsumption) \\
Corporate social responsibility from companies & Lack of corporate social responsibility from companies \\
and stakeholders & and stakeholders \\
Rising social trust & Awareness of social trust \\
\hline
\end{tabular}

Source: elaborated based on (Sulich and Zema 2018)
Environmental goods are related to environmental services as they arise from environmental processes. Then environmental products can be the primary, secondary or auxiliary manufacturer's production and serve EP or RM. The green terminology also introduces the environmental producers' concept, which refers to producers involved in pro-environmental solutions (Broniewicz and Domańska 2016).

The regulation EU No. 691/2011 lists the environmental activities and products under the EGSS (Eurostat 2020b). "The EGSS reporting collects, collates, and reports information on market output (including export), value-added of market activities, employment of market activities" (Eurostat 2020b). Among several outputs, there are the "non-market, for own final use, ancillary environment, and gross value added and employment" (UNEP 2008; Sulich et al. 2020). The EGSS considers the economic activities responsible for generating products which base is the environment, such as those produced for EP or RM. To support initiatives related to EP, the EU Commission has precisely defined environmental products and activities (Sugiyono and Dewancker 2020). "Products for EP prevent, reduce, and eliminate pollution or any other degradation of the environment. They include measures undertaken to restore degraded habitats and ecosystems. Examples are electric vehicles, catalysts, and filters to decrease pollutant emissions, wastewater, and waste treatment services, or noise insulation works. Products for RM safeguard the stock of natural resources against depletion. Examples are renewable energy production, energy-efficient, and passive buildings, seawater desalinization, or rainwater recovery" (Eurostat 2020b).

The EGSS is the sector where Green Jobs are created next to the EP activities (Ernst et al. 2019), which are categorized according to the Classification of Environmental Protection Activities (CEPA). Also related to the EGSS is the list Classification of Resource Management Activities (CReMA) associated with Green Jobs (Eurostat 2020b). These classifications distinguish sixteen categories and subcategories (Eurostat 2020b) which are following the Statistical Classification of Economic Activities in the European Community (NACE 2) (European Commision 2008).

The EGSS meets environmental goals, i.e., industry enterprises' goods and services help to preventing, reducing, and eliminating ecological degradation or protecting and maintaining natural resources (Livesey 2010; Eurostat 2015).
Fig. 1 Product life cycle and its linear and circular economy implications. Source: Authors' elaboration

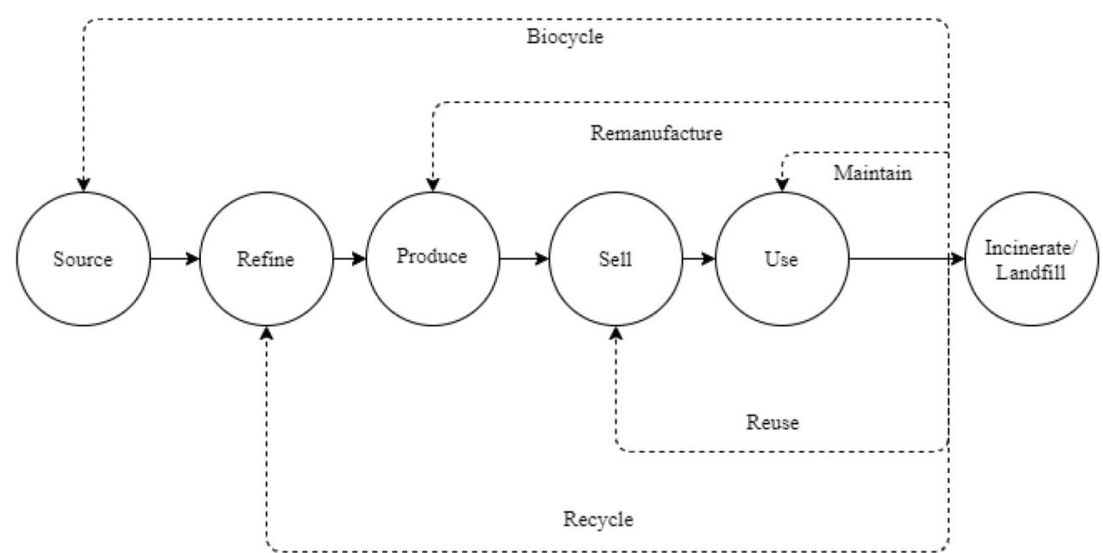


The EGSS is related to the CE because closing linear chains into loops creates direct and indirect (induced) Green Jobs based on technology development. These expand the EGSS into new EP and RM-related processes and creates new jobs (Karaferye and Agaoglu 2017; Xu et al. 2020). The EGSS is a part of strategic importance in building a CE in the EU (Durán-Romero et al. 2020).

Crowley (1999) notes, in the modern world, enterprises' orientation toward environmental friendliness should be treated as a higher good. The approach to environmental protection changes, which is not treated as an economic burden, but constitutes a development opportunity (D'Adamo and Lupi 2021) and allows for jobs creation (Crowley 1999).

\section{Green Jobs in circular economy model}

Observed climate and technological changes not only generate threads but also open some opportunities associated with the creation of the Green Jobs (GJs). On the other hand, investments in GJs bring relevant economic, environmental, and social benefits. The benefits of GJs vary, as they generate environmental benefits in traditional and new sectors (Esposito et al. 2014). The GJs creation is associated with a new approach to business management, aiming to prevent environmental degradation and reduce unemployment (Sulich et al. 2020; McMahon et al. 2021). Therefore, GJs are essential for protecting the environment and the labor market, combining sustainability principles (Paes et al. 2019; Unay-Gailhard and Bojnec 2019).

The Green Jobs (GJs) definition used in this article is accepted after the UNEP (2008) term. The Eurostat has not defined GJs explicitly but it appears in the context of the EGSS (Livesey 2010). Despite the lack of the GJs definition in EU documents, its main assumptions are reflected in EU initiatives targeting the so-called balance of two major concerns: the environment and economic growth. The potential of Green Jobs is promising as the CE should help protect the environment and ensures decent work (Toan et al. 2016). The International Labour Organization (ILO) has proposed the term of decent work. "Decent work sums up the aspirations of people in their working lives. It involves opportunities for work that is productive and delivers a fair income, security in the workplace and social protection for families, better prospects for personal development and social integration, freedom for people to express their concerns, organize and participate in the decisions that affect their lives, and equality of opportunity and treatment for all women and men" (ILO 2020). Decent work is recognized as part of the Sustainable Development Goals' achievement in the formulated by the EU document titled "2030 Agenda for the SD" (United Nations 2021). Therefore, each definition of GJs presented in Table 2 has a multidimensional impact (Pettinger 2017).
According to Table 2 and Harvey et al. (2010), the organizations create GJs where resources, such as health, time, talent, and money, are not wasted. This new trend responds to the particular need for organizations to be pro-ecologically involved and generating less waste and reducing emissions. Observed changes are a challenge for employers, as it is necessary to reconcile the "eco" and green approaches when managing the organization, making profits, and being competitive (Sołoducho-Pelc and Sulich 2020).

The idea of the CE development and the evolution of SD affects the work and competence of employees. The research carried out by Song and Xie (2019) has already shown that economic development is influenced by the green labor participation rate, the GJs, and green talent (Song and Xie 2019). Therefore, both the needs and expectations of new employee competencies are growing (Burger et al. 2019). Considering the aforementioned contributions, an analytical display of the different definitions relating to GJs as in Figure 2 was presented.

The Green Jobs Initiative (ILO 2021) was created by the international organizations the International Labor Organization (ILO) and the United Nations Environment Program (UNEP) and the International Trade Union Confederation (ITUC). The initiative is covering the impacts caused by climate change on employment and how to mitigate undesirable consequences for future programs. This initiative also supports governments and employers' efforts in promoting sustainable and environmentally Green Jobs targeting climate change issues. This initiative has a set of goals: "to promote awareness and dialog; to identify and respond to knowledge gaps; to facilitate a "just transition" that reflects the environmental, economic and social pillars of sustainable development; to promote policies and measures to achieve Green Jobs; to catalyze employment and poverty alleviation within climate mitigation and adaptation programs; and to strengthen collaboration between UNEP/ILO/ITUC, within the UN system and with the international business community to establish a common "Green Jobs" definition" (UNEP 2008).

The impact of the GJs on the labor market and employment can be distinguished from a broad conceptual perspective, in at least four ways as the economy is oriented toward greater sustainability and CE. "First, in some cases, additional jobs will be created - as in the manufacturing of pollution-control devices added to existing production equipment. Second, some employees will be substituted - as in shifting from fossil fuels to renewables, or from truck manufacturing to rail car manufacturing, or from landfilling and waste incineration to recycling. Third, certain jobs may be eliminated without direct replacement - as when packaging materials are discouraged or banned and their production is discontinued. Fourth, it would appear that many existing jobs (especially such as plumbers, electricians, metal workers, and construction workers) will simply be transformed and redefined as day- 
Table 2 Green Jobs definitions

\begin{tabular}{ll}
\hline Organization & Definition \\
\hline Bureau of Labor Statistics (BLS) & Green Jobs are as follows: \\
& a) Jobs related to the goods manufacturing/services providing that can benefit the \\
& environment or save natural resources. \\
& b) Jobs devoted to establishing environmentally friendly production processes and \\
& less use of resources from natural sources made by workers. \\
& Categories of green goods/services/technologies are available at the BLS Green \\
Jobs definition. & \\
"Green Jobs are workplaces in agricultural, manufacturing, research and \\
development, administrative, and service activities that contribute substantially \\
to preserving or restoring environmental quality. Specifically, but not \\
exclusively, this includes jobs that help to protect ecosystems and biodiversity; \\
reduce energy, materials, and water consumption through high-efficiency \\
Program (UNEP) \\
strategies; de-carbonize the economy; and minimize or altogether avoid the \\
generation of all forms of waste and pollution.” (UNEP 2008) \\
In the context of economic sectors, Green Jobs are responsible for reducing the \\
environmental impacts of such economic activities performed by for-profit \\
companies. Green Jobs also provide the support for decent work and improving \\
workforce living conditions and greater considerations of labor rights. \\
Green Jobs relate to those that reduce environmental impacts and promote \\
sustainability. Green Jobs include those that are related to the reduction of \\
several consumptions of energy/raw materials, those related to the \\
decarbonization of the economy, those that promote ecosystems and biodiver- \\
confederation (ITUC) \\
sity protection/restoration, and those that reduce waste and pollution generation. \\
The broad focus of the Green Jobs concept encompasses any new position that \\
shows a smaller than average environmental footprint. \\
No definition of Green Jobs in the context of EGSS. However, consider EGSS \\
employment for measuring procedures.
\end{tabular}

Sources: (UNEP 2008; Rutkowska-Podołowska et al. 2016; Bureau of Labor Statistics 2020; Eurostat 2020a; UNEP 2020).

to-day skill sets, work methods, and profiles are greened" (UNEP 2008).

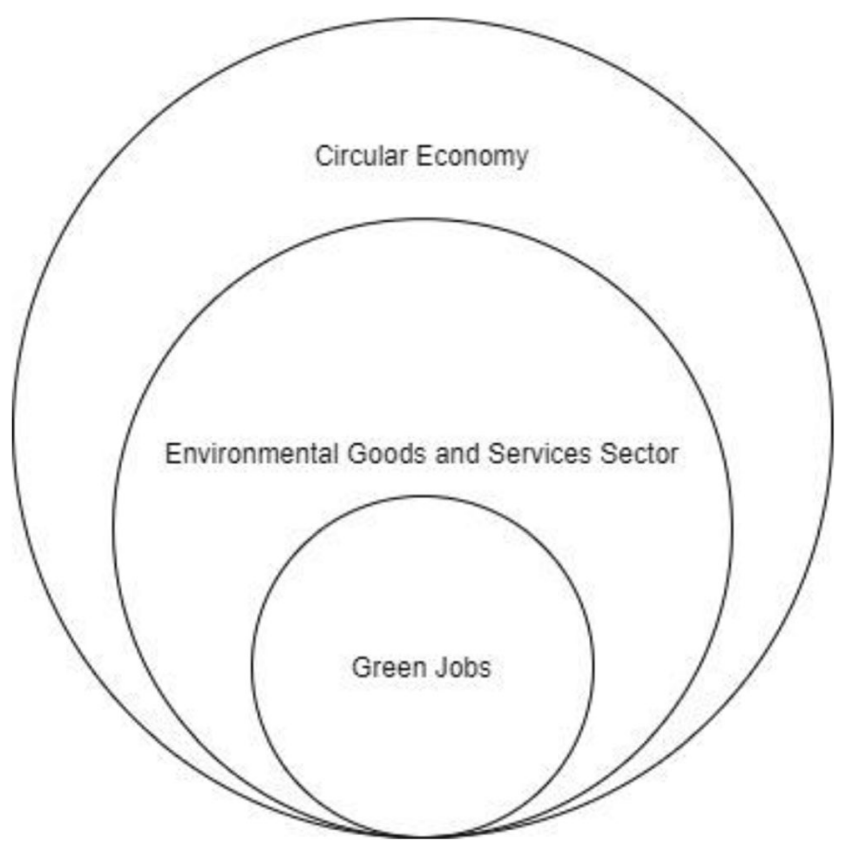

Fig. 2 Relations between CE, EGSS, and GJs. Source: Authors' elaboration
Figure 3 shows the relations between the three areas of employment: (1) production of green products and services, (2) environmental processes (EP), and (3) resources management (RM). There are GJs in the shaded part of Figure 3 and these are part of the EGSS employment (Livesey 2010). They can be described as pure GJs because these jobs are created in a unique environment created by the sector related directly to the natural environment (Sulich and Zema 2018).

Presented in Table 2 definitions can be operationalized based on two core elements, which are consistent with the output and process approaches (Bureau of Labor Statistics 2020). In the EGSS context, the EP and RM approaches bring focus on the goods and services outputs and indicators suitable for the CE (Piwowar-Sulej 2021). Additionally, the problem of measurability and objectivity in evaluation appears in scientific research and reporting on the GJs worldwide, and in this context, explanatory model combining CE and GJs is required (Gagliardi et al. 2016; Dordmond et al. 2021).

\section{Research design}

The adopted research method is the statistical linear regression method. This method is mostly used in the research of the economic development comparisons (Kasztelan 2016; 
Fig. 3 Green Jobs as an area between core elements of revised definitions and EGSS elements Source: (Sulich and Zema 2018).

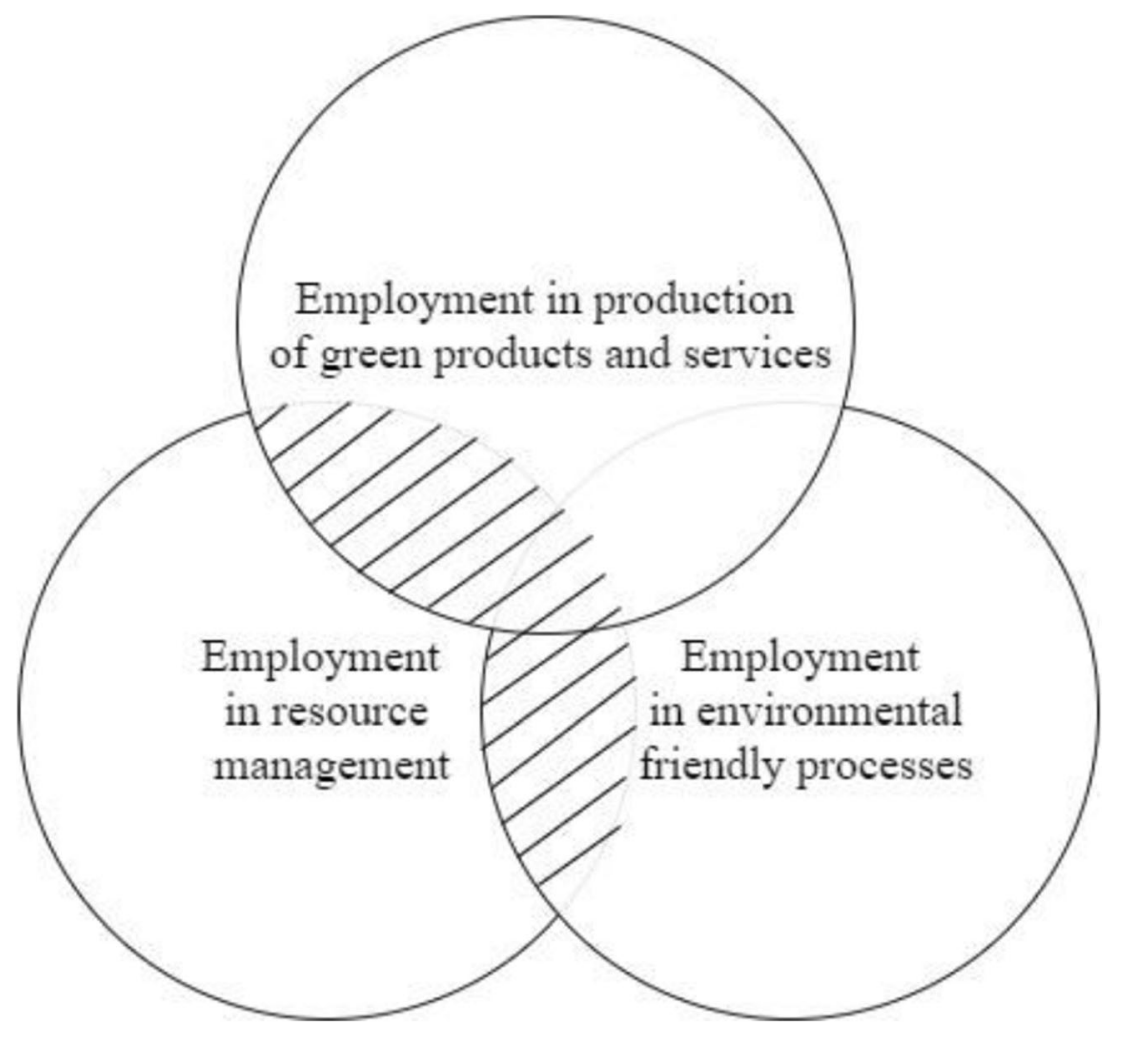

Raszkowski 2018; Moraga et al. 2019; Sulich et al. 2020) related to the usage of the full set of variables to create an econometric model. In this research data obtained from the Eurostat database for all 28 EU countries in years, 20092019 were used, because of their reliability (Eurostat 2020c). What is more, the EGSS data are made available every year, and these data are also part of the sustainable development indicators (more than 100 overlapping variables in a very wide context), gathered in the Eurostat database grouped in 17 sustainable development goals (SDGs) (Schroeder et al. 2019; Rincón-Moreno et al. 2020). Then, among these indications, there is also a distinguished group of the $\mathrm{CE}$ which consists of 15 indicators. In the research method, they are considered as the describing independent variables (with symbols from CE_1 to CE_15) to the variable with symbol GJs - Green Jobs (described variable). All variables related to the CE and EGSS employment were identified for further calculations performed with the Statistica ${ }^{\circledR}$ Software. Presented in Table 3, variables are given by Eurostat to measure CE transition among EU countries and were not the result of the authors' choice. The Green Jobs variable (GJs) which employment is in the EGSS is adopted in this paper. Data on EGSS are widely applicable and are used in the economy, politics, and social activities (Demidova et al. 2021). Both in microeconomics and macroeconomics, these data are used to formulate environmental management goals and to monitor them (Eurostat 2015). In Table 3, there are three variables marked with * symbol, which are not used in calculations due to their characteristics: CE_1 (cei_pc010); CE_7 (cei_wm020); and CE_11 (cei_srm010). These variables are not associated with EU member states, but with the specified resources and are listed by Eurostat to describe CE. Therefore, continuous enumeration of these indicators was kept in accordance with the Eurostat database (Eurostat 2020c).

The presented division of the variables is in order with the method adopted by the Eurostat (Eurostat 2020c). The performed multiple regression aim was to create the econometric model to cover described in the introduction section research gap and to propose a reliable model based on the variables proposed by Eurostat.

\section{Data analysis and discussion}

This paper has researched the secondary data related to the $\mathrm{CE}$ indicators gathered for each EU member state in years 20092019 and published in the Eurostat database in a dedicated section entitled "Circular economy indicators" (Eurostat 2020f). The two sets of variables in a total number of 13 , which were based on the Eurostat database were defined. The first set of 12 variables (symbols as in Table 3) are describing and independent variables when the one variable with symbol GJs is dependent and described variable.

The correlation (Table 4) and basic statistics (average and standard deviation values) for unstandardized data, aiming to check interdependencies between variables were examined. 
Table 3 Chosen indicators measured by the Eurostat (Eurostat 2020d)

\begin{tabular}{|c|c|c|c|}
\hline Indicator group & Variable symbol & Indicator characteristic & Eurostat symbol \\
\hline \multirow[t]{4}{*}{ Production and consumption } & CE_1* & EU self-sufficiency for raw materials & (cei_pc010) \\
\hline & $\mathrm{CE} 2$ & Generation of municipal waste per capita & (cei pc031) \\
\hline & CE_3 & Generation of waste excluding major mineral wastes per GDP unit & (cei_pc032) \\
\hline & CE 4 & Generation of waste excluding major mineral wastes per domestic material consumption & (cei_pc033) \\
\hline \multirow[t]{6}{*}{ Waste management } & CE_5 & Recycling rate of municipal waste & (cei_wm011) \\
\hline & CE_6 & The recycling rate of all waste excluding major mineral waste & (cei_wm010) \\
\hline & $\mathrm{CE}_{-}^{-} 7 *$ & The recycling rate of packaging waste by type of packaging & (cei_wm020) \\
\hline & CE_-8 & Recycling rate of e-waste & (cei_wm050 \\
\hline & CE_9 & Recycling of biowaste & (cei_wm030) \\
\hline & CE_-10 & The recovery rate of construction and demolition waste & (cei_wm040) \\
\hline \multirow[t]{3}{*}{ Secondary raw materials } & CE_-11* & $\begin{array}{l}\text { Contribution of recycled materials to raw materials demand -end-of-life } \\
\text { recycling input rates (EOL-RIR) }\end{array}$ & (cei_srm010) \\
\hline & CE_12 & Circular material use rate & (cei_srm030) \\
\hline & CE_-13 & Trade in recyclable raw materials & (cei_srm020) \\
\hline \multirow{2}{*}{ Competitiveness and innovation } & CE_-14 & Private investments, jobs, and gross value added related to circular economy sectors & (cei_cie010) \\
\hline & CE_-15 & Patents related to recycling and secondary raw materials & (cei_cie020) \\
\hline Labor market & GJs & Employment in the environmental goods and services sector & (env_ac_egss 1 ) \\
\hline
\end{tabular}

Source: Authors elaboration based on (Eurostat 2020e, 2020f)

*Data were unavailable or not in the geographical breakdown suitable for further research

Moreover, it is intended to find out the directions of the relations of the aforementioned variables. The main research assumption is the correlation examination of variables possesses a sense only a cause-and-effect relation is present. This research used calculations from the Statistica ${ }^{\circledR}$ software made available by StatSoft Poland programming environment. The dependent variable GJs is significantly correlated with variables: CE_5, CE_9, CE_12, CE_13, CE_14, and CE_15, as presented in Table 4.

The regression aimed to identify the primary model based on the reduced number of variables as presented in Table 5.

In Table 5 only significant $(p<0.000001)$ variables for the model were marked with bold text, and the others are insignificant: CE 2; CE 5; CE_10, and this can mean that these variables are collinear (CE_5) with the other independent variables or their correlations are weak with the dependent variable (as explained in Table 4).

As a result, the simplified equation was obtained, representing the relations between GJs and its describing variables CE_14, CE_15, and C_9. The linear model formula (linear polynomial) is presented as Eq. (1):

$\mathbf{G J s}=\mathbf{C E}_{\_} \mathbf{1 4} \cdot 13,5+\mathbf{C E}_{\mathbf{1}} \mathbf{1 5} \cdot 2386,0+\mathbf{C E}_{-} \mathbf{9} \cdot 1156,7$

$$
\pm 0.4146
$$

In Eq. 1, the variables' meaning is the same as in Table 3. The linearity of the presented model was checked in test $F(6,21)=54,482$. We have verified the model, which consists of checking the model assumptions:

1. The significance of linear regression (note under Table 5) is $p<0.000001$;
2. The importance of partial regression coefficients;

3. No collinearity (redundancy) between independent variables:

4. Homoscedasticity assumption, which means that the variance of the random component $\left(\varepsilon_{i}\right)$ is the same for all observations;

5. No residual autocorrelation;

6. Normal residual distribution (Figure 4); and

7. The random term $\varepsilon_{i}$ has the expected value equal to 0 .

The multiple regression coefficient $R=0,96934832$ is a measure of the interdependencies between independent variables (12 qualified to research) and dependent variable (Green Jobs).

Then, the obtained calculations allowed the following results (Sołoducho-Pelc and Sulich 2020):

1. Linear regression's significance was $F=54,48$ with $p<0.000001$. This result proved that Eq. 1 is significant. The coefficient of multiple correlations was $R=0.96$, supporting the linear dependencies between variables (Eq. 1);

2. The $p<0.000001$ value evidence the significance of partial regression coefficients;

3. No collinearity between independent variables was verified, with high tolerance values for both variables (close to 1$)$;

4. Model linearity is supported by the fulfilled homoscedasticity;

5. No residual autocorrelation was identified (Table 8);

6. Normal residual distribution was identified (Figure 4); and 


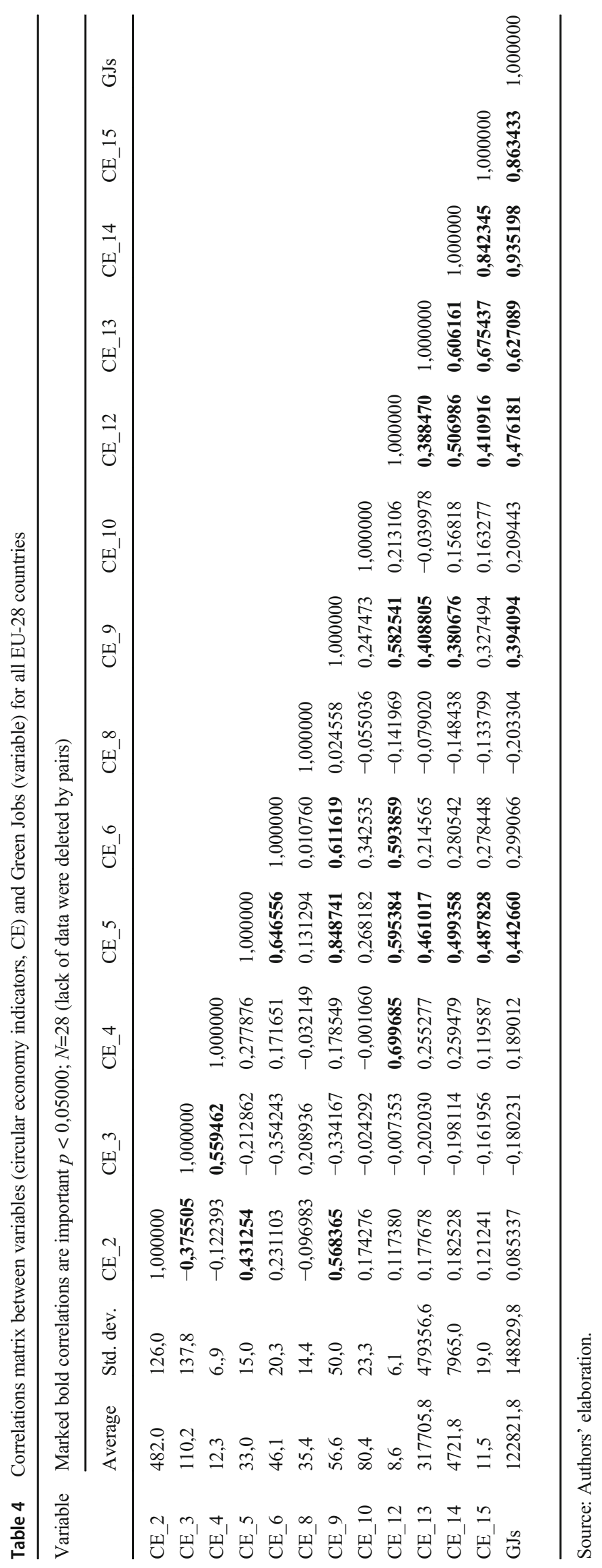


Table 5 Dependent variable GJs regression summary and model characteristics

\begin{tabular}{lllllll}
\hline $\boldsymbol{N}=\mathbf{2 8}$ & $\boldsymbol{b}^{*}$ & Std. Err. $\boldsymbol{~}^{*}$ & $\boldsymbol{b}$ & Std. err. $\boldsymbol{b}$ & $\boldsymbol{t}(\mathbf{2 1})$ & $\boldsymbol{p}$ \\
\hline Intercept & & & 137303,8 & 46242,92 & 2,96919 & 0,007319 \\
CE_14 & $\mathbf{0 , 7 2 1 7 3 5}$ & $\mathbf{0 , 1 0 1 8 1 5}$ & $\mathbf{1 3 , 5}$ & $\mathbf{1 , 9 0}$ & $\mathbf{7 , 0 8 8 7 1}$ & $\mathbf{0 , 0 0 0 0 0 1}$ \\
CE_15 & $\mathbf{0 , 3 0 3 8 9 9}$ & $\mathbf{0 , 1 0 2 5 6 4}$ & $\mathbf{2 3 8 6 , 0}$ & $\mathbf{8 0 5 , 2 6}$ & $\mathbf{2 , 9 6 3 0 2}$ & $\mathbf{0 , 0 0 0 0 0 1}$ \\
CE_2 & $-0,169005$ & 0,065845 & $-199,6$ & 77,76 & $-2,56671$ & 0,017977 \\
CE_9 & $\mathbf{0 , 3 8 8 3 8 3}$ & $\mathbf{0 , 1 1 3 5 7 7}$ & $\mathbf{1 1 5 6 , 7}$ & $\mathbf{3 3 8 , 2 7}$ & $\mathbf{3 , 4 1 9 5 6}$ & $\mathbf{0 , 0 0 0 0 0 1}$ \\
CE_5 & $-0,341973$ & 0,112701 & $-3387,3$ & 1116,32 & $-3,03434$ & 0,006306 \\
CE_10 & 0,071692 & 0,055855 & 457,5 & 356,41 & 1,28354 & 0,213286 \\
\hline
\end{tabular}

Note: Model features: $R=0,96934832 ; R^{2}=0,93963617$; Corrected $R^{2}=0,92238937 ; F(6,21)=54,482$; $p<0.000001$; Error std. estimation $=0.41462$; symbols meaning: $b^{*}$ standard coefficients, $b$ directional coefficient of equation

Source: Authors' calculations
7. The random term $\varepsilon_{i}$ reported an expected value $\left(\varepsilon_{i}=0\right)$ thanks to the average value of the Cook's distance $(=0)$ (Table 7).

In Table 6, the average values and standard deviations for each variable were calculated. For all variables, all 28 cases (which refer to $28 \mathrm{EU}$ countries) were important to calculate the presented multiple regression model (Table 5). Variables symbols used in Table 6 are the same as in Table 3.

The next step of the calculated model verification was to check the residuals normality distribution presented in Figure 4. The plot of the normal distribution of residuals shows that all residuals are arranged along a straight line. The outliers may be the cause of this, and it is assumed that the resulting distribution of residuals is normal.
The statistics shown in Table 7 calculated in regression for variable GJs are used to identify outliers: standardized residuals, residual values removed, Mahalanobis distances, Cook distances. If the observed values among one of these statistics are in the same order, this informs about the lack of outliers. If the observation of calculation results (Table 7) proved differences in these values, then probably, the given case (1-28) and this order is related to the alphabetical order of EU member states as listed in Eurostat tables (Eurostat 2020c) has a significant influence on the regression bias.

In Table 8, the analysis proved the lack of autocorrelation of residuals and statistics value $d=1.947$ and this means that there was enough data to calculate a statistically significant linear model in multiple regression procedure.
Fig. 4 The residuals normality distribution chart. Source: Authors' calculations

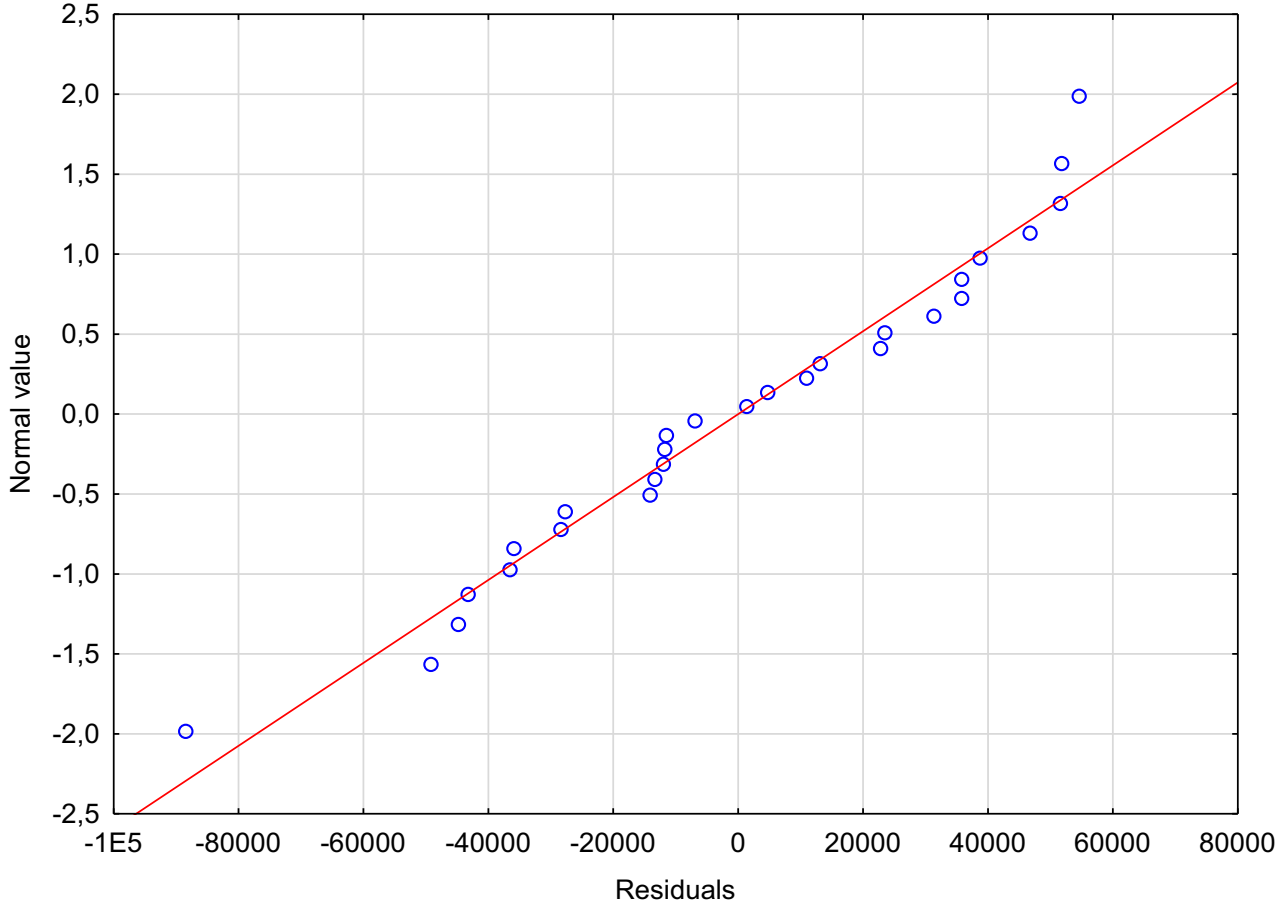


Table 6 Variables and their average and standard deviations values

\begin{tabular}{llll}
\hline Variable & Average & Std. dev. & No. important \\
\hline CE_2 & 482,0 & 126,0 & 28 \\
CE_3 & 110,2 & 137,8 & 28 \\
CE_4 & 12,3 & 6,9 & 28 \\
CE_5 & 33,0 & 15,0 & 28 \\
CE_6 & 46,1 & 20,3 & 28 \\
CE_8 & 35,4 & 14,4 & 28 \\
CE_9 & 56,6 & 50,0 & 28 \\
CE_10 & 80,4 & 23,3 & 28 \\
CE_12 & 8,6 & 6,1 & 28 \\
CE_13 & 317705,8 & 479356,6 & 28 \\
CE_14 & 4721,8 & 7965,0 & 28 \\
CE_15 & 11,5 & 19,0 & 28 \\
GJs & 122821,8 & 148829,8 & 28 \\
\hline
\end{tabular}

Source: Authors' calculations

Figure 5 proved the homoscedasticity assumption, which was fulfilled, supporting the model's linearity. The assumption is met because the points on the graph form an even cloud, without any characteristic pattern of points.

The linear model (Eq. 1) presents the two sets of variables. This equation presents regression results, reducing the number of variables that were used in the final model. Regression allowed the description of statistically significance relations between GJs (Employment in the Environmental Goods and Services Sector) and CE_14; CE_15; CE_9. Variables' dependencies create a model presented in Eq. 1 and Figure 6. The shape of the proposed model underlines the circularity feature of described economy.

The EGSS is a part of the circular economy and in this sector majority of the GJs are visible (Dordmond et al. 2021). However, the GJs can be created in the other sectors of the economy. Obtained results prove the unequivocal character of the three variables with described variable GJs. Thus, CE_14 (Private investments, jobs, and gross value added related to circular economy sectors) represents crucial expenditures related to the development of EGSS. Also significant for the model is variable CE_15 (Patents related to recycling and secondary raw materials), which also indicates that technological progress combined with investments can influence CE 9 (Recycling of biowaste). All these variables used in the model prove that GJs are part of the labor market influenced in the same matter by the inventions and investments, but they are very specific because their aim is reducing the anthropopressure (negative impact of human activity on the natural environment). In this perspective, the GJs are part of the EGSS.

\section{Discussion}

The GJs creation process in the literature is described mostly qualitatively what includes sectors of the economy (Bruyère and Filiberto 2013; Conlon et al. 2019):

1. "Generation of energy from renewable sources (solar, wind, biofuels) including manufacturing, installation, and maintenance;

2. Improving energy efficiency including services like home energy audits, home renovation and retrofitting, and manufacture and provision of products like energy efficiency appliances;

3. Pollution reduction/removal recycling, greenhouse gas reduction;

4. Natural resources conservation including organic agriculture, sustainable forestry, and stormwater management;

5. Environmental compliance, education, and training including regulations and public awareness".

This list of the areas or factors influencing the GJs creation process then is not used in a mathematical method to predict or calculate the number of the GJs but to prove transformation toward the CE (McMahon et al. 2021; Rojas Arboleda et al. 2021). The majority of the quantitative publications document the number of GJs (Ferrão et al. 2015) or are focused on the gap between demand and supply of GJs (Song et al. 2021). However, in the literature, there is a similarity to be presented in this paper, graphical approach describing the relations between GJs and CE (Horbach et al. 2015); these works are qualitative in their methods (Battaglia et al. 2018). Therefore, this paper brings novelty to science and expands GJs creation process quantitative horizon. Contrary to model presented in Eq. 1 and Figure 6, the other publication uses one chosen indicator or factor like the final energy consumption from renewables and income in rural areas (Aceleanu et al. 2018) or utilized agricultural area (Unay-Gailhard and Bojnec 2019). The model presented in this paper is supported by findings of Luca et al. (2019) which used multilevel logistic regression and confirmed their hypothesis that "the resources efficiency actions a company is taking, the more likely it is for employees to have a green job" (Luca et al. 2019, p. 69). Contrary to Luca et al. (2019), this paper covers 2009 and 2019 for all EU member states, and based on secondary data from Eurostat, the linear model of the Green Jobs creation process has been proposed. This research proposed the Green Jobs creation econometric model connected to the CE. This model describes relations between theoretical assumptions of CE and empirical implications in the emerging GJs using indicators constructed upon the Sustainable Development Goals (SDGs). Also, other papers examine the number of GJs in the CE (Mehmet 1995; Moreno-Mondéjar et al. 2021), but their methods are based on the strategies 
Table 7 Expected values and residuals in regression for variable GJs (Green Jobs)

\begin{tabular}{|c|c|c|c|c|c|c|c|c|c|}
\hline & Obs. value & Predict value & Residual & Std. Predict & Std. residual & Std. err predict value & Mahaln dist. & Deleted residuals & Cook dist \\
\hline 1 & 33876,000000 & 45305,078125 & $-11429,078125$ & $-0,537311$ & $-0,275652$ & 27671,212891 & 11,061666 & $-20607,994141$ & 0,015719 \\
\hline 2 & 38150,000000 & 6771,692871 & 31378,306641 & $-0,804407$ & 0,756797 & 14358,762695 & 2,273865 & 35654,390625 & 0,012670 \\
\hline 3 & 113816,000000 & 7998,562500 & 35817,437500 & $-0,310695$ & 0,863862 & & & 43603,042969 & 0,028210 \\
\hline 4 & 68880,000000 & 57890,308594 & 10989,691406 & $-0,450076$ & & & & & 0,007804 \\
\hline 5 & 517348,500000 & 560558,312500 & $-43209,812500$ & 3,034193 & $-1,042154$ & 36519,644531 & 19,982437 & $-192732,781250$ & 0,394775 \\
\hline 6 & 30264,000000 & 43534,156250 & $-13270,156250$ & $-0,549586$ & $-0,320056$ & 14679,734375 & 2,420252 & $-15172,018555$ & 0,002398 \\
\hline 7 & 24308,000000 & $-11510,732422$ & 35818,734375 & $-0,931133$ & 0,863893 & 19665,970703 & 5,109980 & 46216,097656 & 0,039932 \\
\hline 8 & 0,000000 & 6865,665527 & $-6865,665527$ & $-0,803756$ & $-0,165589$ & 29473,783203 & 12,679496 & $-13879,150391$ & 0,008089 \\
\hline 9 & 302615,000000 & 255867,062500 & 46747,937500 & 0,922210 & 1,127488 & 13346,864258 & 1,833545 & 52152,117188 & 0,023421 \\
\hline 10 & 455745,000000 & 416986,437500 & 38758,562500 & 2,039017 & 0,934797 & 20986,066406 & 5,952830 & 52108,113281 & 0,057806 \\
\hline 11 & 36806,000000 & 50881,167969 & $-14075,167969$ & $-0,498660$ & $-0,339471$ & 12295,106445 & 1,409970 & $-15432,205078$ & 0,001740 \\
\hline 12 & 380626,000000 & 329004,687500 & 51621,312500 & 1,429167 & 1,245027 & 18309,621094 & 4,300997 & 64126,687500 & 0,066640 \\
\hline 13 & 0,000000 & $-1393,591675$ & 1393,591675 & $-0,861005$ & 0,033611 & 22036,017578 & 6,662284 & 1942,194824 & 0,000089 \\
\hline 14 & 26767,500000 & 55095,511719 & $-28328,011719$ & $-0,469448$ & $-0,683228$ & 13874,701172 & 2,059216 & $-31900,251953$ & 0,009470 \\
\hline 15 & 33121,500000 & 45034,687500 & $-11913,187500$ & $-0,539185$ & $-0,287328$ & 10761,227539 & 0,854521 & $-12773,662109$ & 0,000913 \\
\hline 16 & 9837,500000 & 45711,902344 & $-35874,402344$ & $-0,534491$ & $-0,865235$ & 19152,716797 & 4,797058 & $-45605,937500$ & 0,036881 \\
\hline 17 & 0,000000 & 49183,089844 & $-49183,089844$ & $-0,510431$ & $-1,186221$ & 12053,177734 & 1,317454 & $-53723,175781$ & 0,020269 \\
\hline 18 & 3787,000000 & 31434,568359 & $-27647,568359$ & $-0,633455$ & $-0,666817$ & 25984,638672 & 9,640365 & $-45530,246094$ & 0,067660 \\
\hline 19 & 137132,500000 & 181922,750000 & $-44790,250000$ & 0,409661 & $-1,080272$ & 18847,197266 & 4,614717 & $-56455,671875$ & 0,054728 \\
\hline 20 & 169589,000000 & 146748,609375 & 22840,390625 & 0,165850 & 0,550875 & 25761,769531 & 9,459234 & 37202,746094 & 0,044402 \\
\hline 21 & 203844,500000 & 199061,875000 & 4782,625000 & 0,528462 & 0,115350 & 23490,330078 & 7,702166 & 7043,419434 & 0,001323 \\
\hline 22 & 102502,000000 & 89345,914063 & 13156,085938 & $-0,232040$ & 0,317305 & 12774,961914 & 1,598913 & 14536,040039 & 0,001667 \\
\hline 23 & 171786,000000 & 117132,953125 & 54653,046875 & $-0,039433$ & 1,318147 & 20211,140625 & 5,451424 & 71687,304688 & 0,101477 \\
\hline 24 & 23838,000000 & 354,105560 & 23483,894531 & $-0,848891$ & 0,566395 & 19622,796875 & 5,083339 & 30262,208984 & 0,017046 \\
\hline 25 & 0,000000 & 88470,695313 & $-88470,695313$ & $-0,238107$ & $-2,133777$ & 18716,539063 & 4,537632 & $-111112,648438$ & 0,209064 \\
\hline 26 & 134214,000000 & 82403,500000 & 51810,500000 & $-0,280162$ & 1,249590 & 10352,226563 & 0,718894 & 55255,105469 & 0,015817 \\
\hline 27 & 55858,000000 & 67571,953125 & $-11713,953125$ & $-0,382967$ & $-0,282523$ & 17488,029297 & 3,839070 & $-14248,854492$ & 0,003002 \\
\hline 28 & 364299,000000 & 400780,093750 & $-36481,093750$ & 1,926682 & $-0,879868$ & 31462,785156 & 14,583098 & $-86005,632813$ & 0,353955 \\
\hline
\end{tabular}

Source: Authors' calculations

which we have considered as processes closing the loops in CE (Figure 1).

The literature review also underlines a lack of uniform methods for measuring and forecasting the effects of Green Jobs creation. This research contributes to science by identifying the green indicators of $\mathrm{CE}$ required in the GJs creation. In the article, we proposed new approaches to the studied issues, summarized in the form of tables and figures. The method used in this study comprises the variables identified in earlier studies and that have been validated by the decision-

Table 8 The $d$ Durbin-Watson model verification

\begin{tabular}{lll}
\hline Feature & $d$ Durbin-Watson & Residual serial correlation \\
\hline Estim. & 1,947020 & 0,006487 \\
\hline
\end{tabular}

Source: Authors' calculations makers in 28 EU countries (Luca et al. 2019, p. 70). The presented model in Figure 6 is a novelty because it combines factors influencing GJs creation in EGSS, from a CE perspective. This model summarizes our research as it identifies three of the most important variables for Green Jobs creation. Based on this model, policy-makers should enhance the investments from private sectors, gross value added, and jobs that are characterized as CE sectors (CE_14), which is the most important variable in the proposed model. The importance for $\mathrm{CE}$ is technology development which is also crucial for the number of patents focusing on the recycling and the use of secondary raw materials (CE_15). The proposed model can be used to predict the number of GJs created in the CE with certain accuracy (Eq. 1). There is a consistency between assumption presented in Figure 1 where $\mathrm{CE}$ is created along with the new processes and Green Jobs to cover material cycles. The interdependencies between CE, GJs, and EGSS, also proved the importance of the SDGs. Similarly to the Luca 
Fig. 5 Observed values with residuals' squares Note: $\alpha=0.95$ and $p<0.000001$ for the regression. Source: Authors' calculations

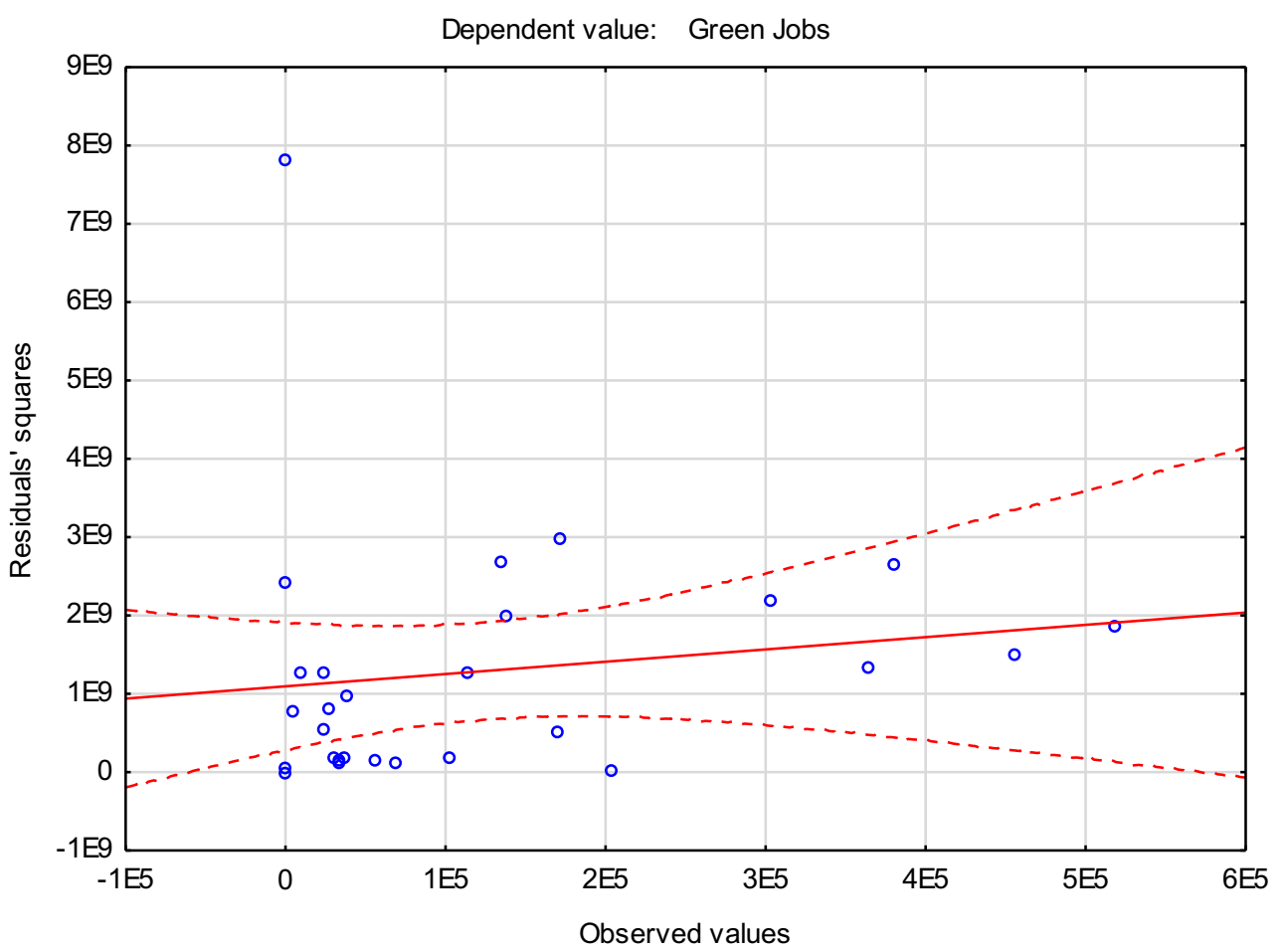

Figure 3, what allowed us to use linear regression as main statistical methods in this study.

Fig. 6 Green Jobs creation model for circular economy Source: Authors' elaboration

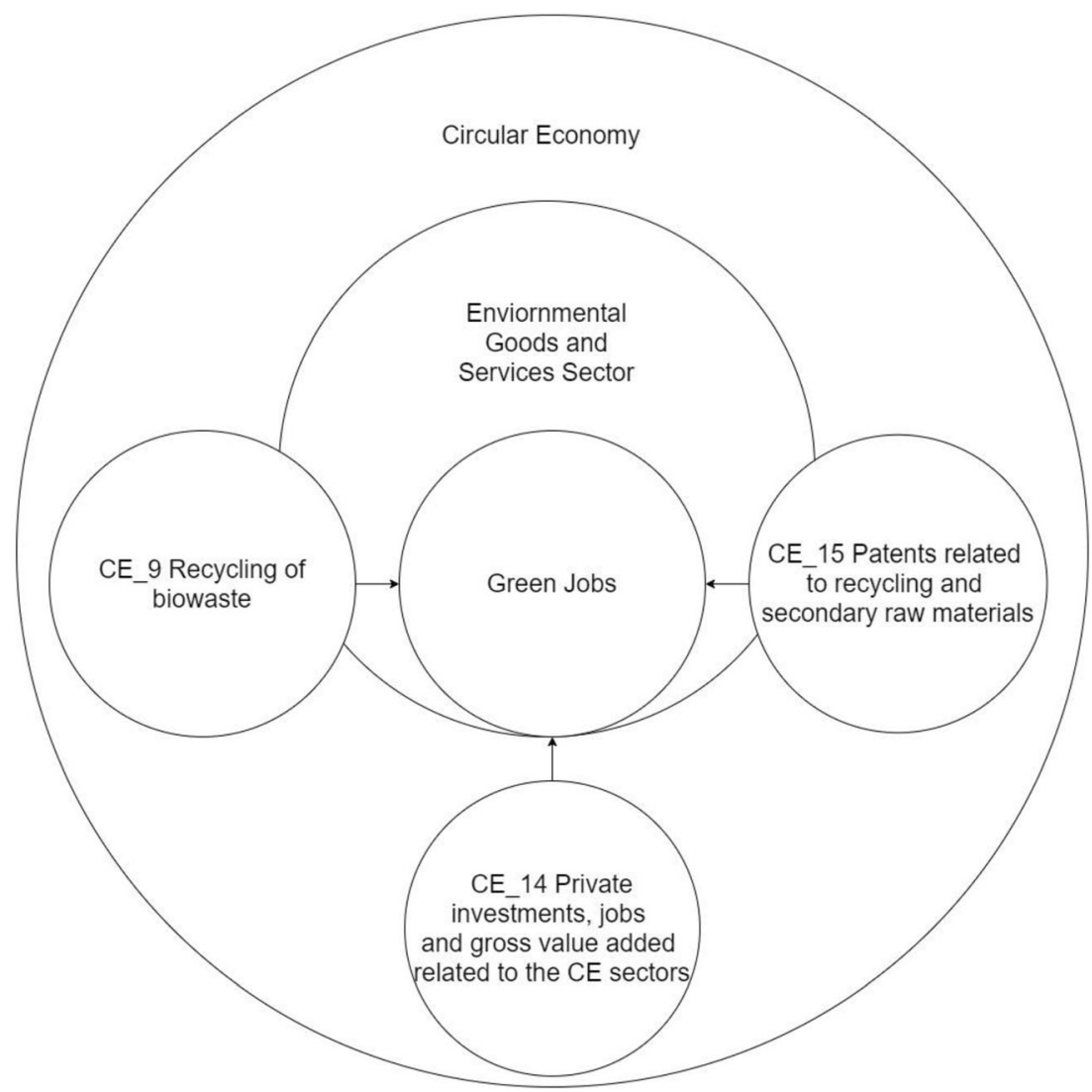




\section{Conclusions and implications}

In the $\mathrm{CE}$, people prevent environmental damage, control pollution, and take measures to protect the enterprise's environment (Tang et al. 2018; Liu et al. 2020). Issues such as development in harmony between humanity and nature, the SD, wise science, and technology are gaining strategic importance. These concepts are crucial for CE development and indicate the need for agreement between the participants of economic processes at the various levels. Therefore, it is assumed that CE is related to the idea of "green civilization" coined by Norgaard (1994), where societies' wisdom translates into civilization development regarding the natural environment and economic benefits for all (Vokoun and Jílková 2020; Wilts et al. 2021).

In the $\mathrm{CE}$, the labor market can be shaped by activities at the macro and micro levels associated with GJs creation. A post-industrial civilization requires a different approach to employees. The honesty of the organization toward its stakeholders, following the proclaimed principles and values, and high moral standards, enforce enterprises toward the natural environment protection. The GJs must appear not only in politicians' messages but mainly in business leaders and employees' minds. The recommended approach is an integrated one toward GJs, where the organization's standards translate into expectations toward employees and achieving specified SDGs. The implementation of the CE indicators and measurement of changes effects in culture and awareness at enterprises, employees, and individual recipient's level allows to closing production cycles. The EGSS is a special environmental sector of the economy where specifically but not exclusively GJs are created. Besides that, this sector aims to reduce or eliminate environmental pressures. The GJs number is increasing due to technological changes and growing investments in EP and RM.

The main findings revealed in the proposed explanatory model of GJs creation are reflected in striving to implement the idea of CE. The model is indicating which strategic management fields can support a $\mathrm{CE}$ and enhance employment in EGSS which in this paper is described as GJs. Presented calculations are rare in the field of the CE scientific discussion about factors of GJs creation. The authors understand that each of the used indicators represents a process that supports the transformation toward the $\mathrm{CE}$ in the EU. The limitation of this study lies in the initial number of variables describing the CE proposed by Eurostat and adopted to this study. On the other hand, this set is comparable and widely accepted due to the Eurostat methodology. These features allow repeating the whole research procedure with scientific objectivity. Then authors could not choose arbitrary variables, other than those adopted in this study. Another limitation comes from the geographical characteristic of variables; they represent EU member states' context only.
When pointing to the possibilities of implementing the CE model in practice, it should be considered that the GJs are next to the pillar of this concept, and they are necessary to achieve SDGs. Green Jobs act as a CE implementation tool and are a strategic goal for organizations in the economic model. The natural environment can be protected and restored by increasing the number of GJs. The GJs importance is not only based on protecting and developing the natural environment. Green Jobs are essential to employees because they ensure decent work and shape their destiny and the environmental protection level. Practitioners and entrepreneurs can focus also on the recycling of biowaste (CE_9) processes which also contribute to the GJs creation as presented in Figure 6. The simplicity of the proposed model can be suitable for the business because it translates theoretical findings into business language and is easy to implement business solutions. The GJs creation processes and factors are important because they offer a combined solution for climate, economic, and social crises.

The future research direction can be based on the replication of the research, the factor analysis usage; this type of method could better describe variability among observed and correlated variables used in this research. This study presents the dynamic changes in the years 2009-2019 for the GJs creation process in $\mathrm{CE}$ and satisfies the demand for similar longitudinal studies (Luca et al. 2019) which should be continued in the future (see Appendix Table 9).

\section{Appendix}

Table 9 Appendix. Regression statistics summary

\begin{tabular}{ll}
\hline Statistical feature & Values \\
\hline$R$ multiple & 0,969348325 \\
Multiple $R^{2}$ & 0,939636174 \\
Corrected $R^{2}$ & 0,922389367 \\
$F(6,21)$ & 54,4817458 \\
$p$ & 0,0000000000101275195 \\
Err. std. estimation & 0.41462 \\
\hline
\end{tabular}

Source: Authors' calculations

Acknowledgements We are grateful to Prof. Marcos Ferasso from the Institute of Scientific Research and Graduate School, Universidad de Lima in Peru for his consultations and discussion of this paper.

Author contribution AS and LSP conceptualized the research, designed and supervised material development, data collection, analysis, literature review, writing, and critical review processes of the research. AS and LSP was involved in supervision, material development, literature review, writing, and critical review processes. Finally, AS and LSP were active 
in supervision while also contributing to the literature review, writing, and critical review of the research and manuscript. All authors read and approved the final manuscript.

Funding The project is financed by the National Science Centre in Poland under the program "Business Ecosystem of the Environmental Goods and Services Sector in Poland" implemented in 2020-2022 project number 2019/33/N/HS4/02957 total funding amount 120,900.00 PLN.

Data availability Not applicable

Code availability Not applicable

\section{Declarations}

Ethics approval and consent to participate Not applicable

Consent for publication Not applicable

Competing interests The authors declare no competing interests.

Open Access This article is licensed under a Creative Commons Attribution 4.0 International License, which permits use, sharing, adaptation, distribution and reproduction in any medium or format, as long as you give appropriate credit to the original author(s) and the source, provide a link to the Creative Commons licence, and indicate if changes were made. The images or other third party material in this article are included in the article's Creative Commons licence, unless indicated otherwise in a credit line to the material. If material is not included in the article's Creative Commons licence and your intended use is not permitted by statutory regulation or exceeds the permitted use, you will need to obtain permission directly from the copyright holder. To view a copy of this licence, visit http://creativecommons.org/licenses/by/4.0/.

\section{References}

Aceleanu MI, Șerban AC, îrcă DM, Badea L (2018) The rural sustainable development through renewable energy. The case of Romania. Technol Econ Dev Econ 24:1408-1434. https://doi.org/10.3846/ 20294913.2017.1303650

Baer P, Brown MA, Kim G (2015) The job generation impacts of expanding industrial cogeneration. Ecol Econ 110:141-153. https://doi.org/10.1016/j.ecolecon.2014.12.007

Barreiro-Gen M, Lozano R (2020) How circular is the circular economy? Analysing the implementation of circular economy in organisations. Bus Strateg Environ 29:1-11. https://doi.org/10.1002/bse.2590

Bartniczak B, Raszkowski A (2019) Sustainable development in African countries:an indicator-based approach and recommendations for the future. Sustainability 11:1-23. https://doi.org/10.3390/su11010022

Battaglia M, Cerrini E, Annesi N (2018) Can environmental agreements represent an opportunity for green jobs? Evidence from two Italian experiences. J Clean Prod 175:257-266. https://doi.org/10.1016/j. jclepro.2017.12.086

Boulding KE (1966) The economics of the Coming Spaceship Earth. In H. Jarrett (Ed.), Environmental Quality in a Growing Economy (pp. 3-14). Baltimore: Johns Hopkins University Pres

Briguglio M, Brown M (2019) Civil society perspectives on green jobs in sustainable energy: the case of European Malta. Energy Environ 30: 867-881. https://doi.org/10.1177/0958305X18813685
Broniewicz E, Domańska W (2016) Environmental goods and services sector accounts. Wiadomości Stat Polish Stat 61:17-30. https://doi. org/10.5604/01.3001.0014.0968

Bruyère SM, Filiberto DM (2013) The green economy and job creation : inclusion of people with disabilities. Int J Green Econ 7:257-275. https://doi.org/10.1504/IJGE.2013.058151.This

Bureau of Labor Statistics (2020) Green Jobs : U.S. Bureau of Labor Statistics. https://www.bls.gov/green/overview.htm. Accessed 23 Dec 2020

Burger M, Stavropoulos S, Ramkumar S, Dufourmont J, van Oort F (2019) The heterogeneous skill-base of circular economy employment. Res Policy 48:248-261

Castillo Castillo A, Angelis-Dimakis A (2019) Analysis and recommendations for European carbon dioxide utilization policies. J Environ Manag 247:439-448. https://doi.org/10.1016/j.jenvman.2019.06. 092

Conlon K, Jayasinghe R, Dasanayake R (2019) Circular economy: wasteto-wealth, jobs creation, and innovation in the global south. World Rev Sci Technol Sustain Dev 15:145-159. https://doi.org/10.1504/ WRSTSD.2019.099377

Corrêa HL, Corrêa DG (2021) The Covid-19Pandemic - opportunities for circular economy practices among sewing professionals in the city of Curitiba-Brazil. Front Sustain 2:1-9. https://doi.org/10.3389/ frsus.2021.644309

Crowley K (1999) Jobs and environment: the "double dividend" of ecological modernisation? Int J Soc Econ 26:1013-1027. https://doi. org/10.1108/03068299910245787

D'Adamo I, Lupi G (2021) Sustainability and resilience after COVID-19: a circular premium in the fashion industry. Sustain 13:1-5. https:// doi.org/10.3390/su13041861

de Oliveira CT, Dantas TET, Soares SR (2021) Nano and micro level circular economy indicators: assisting decision-makers in circularity assessments. Sustain Prod Consum 26:455-468. https://doi.org/10. 1016/j.spc.2020.11.024

Demidova S, Balog M, Chircova T, Kulachinskaya A, Zueva S, Akhmetova I, Ilyashenko S (2021) Development of methodology and assessment of ecological safety of the EAEU and CIS regions in the context of sustainable development. Economies 9:. doi: https:// doi.org/10.3390/economies 9030100

Dordmond G, de Oliveira HC, Silva IR, Swart J (2021) The complexity of green job creation: an analysis of green job development in Brazil. Environ Dev Sustain 23:723-746. https://doi.org/10.1007/ s10668-020-00605-4

Durán-Romero G, López AM, Beliaeva T, Ferasso M, Garonne C, Jones P (2020) Bridging the gap between circular economy and climate change mitigation policies through eco-innovations and Quintuple Helix Model. Technol Forecast Soc Change 160:120246. https://doi. org/10.1016/j.techfore.2020.120246

Ernst C, Brizuela ASR, Epifanio D (2019) Green jobs in argentina: opportunities to move forward with the environmental and social agenda. CEPAL Rev 2019:51-71. https://doi.org/10.18356/280A25AA$\mathrm{EN}$

Esposito M, Haider A, Samaan D, Semmler W (2014) Enhancing job creation through green transformation. In K. Schlegelmilch, H. Eichel, \& A. Pegels (Eds.), Green Industrial Policy: Concept, Policies, Country Experiences (Vol. 30, pp. 469-491). Retrieved from https://www.unpage.org/files/public/green_industrial_policy_ book_aw_web.pdf

European Commision (2008) NACE 2 REV - Regulamento Comissão Europeia No.1893/2006 do Parlamento Europeu e do Conselho

Eurostat (2015) A practical guide for the compilation of environmental goods and services (EGSS) accounts. http://ec.europa.eu/eurostat/ documents/1798247/6191549/Practical-guide-towards-compilingEGSS-statistics-March2015.pdf/f0f8c6c1-0ae9-4f53-9c94afcc190cc5ba 
Eurostat (2020a) Environmental economy-statistics on employment and growth. Statistics explained. https://ec.europa.eu/eurostat/ statisticsexplained/

Eurostat (2020b) Environmental goods and services sector. In: Eurostat metadata. https://ec.europa.eu/eurostat/cache/metadata/en/env egs esms.htm. Accessed 22 Dec 2020

Eurostat (2020c) Main tables -circular economy - Eurostat. In: Circ. Econ. https://ec.europa.eu/eurostat/web/circular-economy/indicators/ main-tables. Accessed 22 Dec 2020

Eurostat (2020d) Database - Eurostat. Circ. Econ. Indic.

Eurostat (2020e) Which indicators are used to monitor the progress towards a circular economy? In: Indic. - Circ. Econ. -Eurortat. https:// ec.europa.eu/eurostat/web/circular-economy/indicators. Accessed 22 Dec 2020

Eurostat (2020f) Database - Eurostat. In: Circ. Econ. Indic. https://ec. europa.eu/eurostat/data/database?node_code $=$ cei. Accessed 22 Dec 2020

Ferasso M, Beliaeva T, Kraus S, Clauss T, Ribeiro-Soriano D (2020) Circular economy business models: the state of research and avenues ahead. Bus Strateg Environ 29:3006-3024. https://doi.org/10. $1002 /$ bse. 2554

Ferrão P, Lorena A, Ribeiro P (2016) Industrial ecology and portugal's national waste plans. In: Clift R, Druckman A (eds) Taking stock of industrial ecology. Springer International Publishing, Cham, pp 275-289. https://doi.org/10.1007/978-3-319-20571-7_14

Friant MC, Vermeulen WJV, Salomone R (2020) A typology of circular economy discourses: navigating the diverse visions of a contested paradigm. Resour Conserv Recycl 161:104917. https://doi.org/10. 1016/j.resconrec.2020.104917

Friant MC, Vermeulen WJV, Salomone R (2021) Analysing European Union circular economy policies: words versus actions. Sustain Prod Consum 27:337-353. https://doi.org/10.1016/j.spc.2020.11. 001

Gagliardi L, Marin G, Miriello C (2016) The greener the better? Job creation effects of environmentally-friendly technological change. Ind Corp Chang 25:779-807. https://doi.org/10.1093/icc/dtv054

Gottinger A, Ladu L, Quitzow R (2020) Studying the transition towards a circular bioeconomy - a systematic literature review on transition studies and existing barriers. Sustainability 12. doi: https://doi.org/ $10.3390 / \mathrm{su} 12218990$

Gottwald F-T(2012) Toward sustainable agriculture and food production: an ethically sound vision for the future. In: Climate change and sustainable development, edited by Thomas Potthast and Simon Meisch, 307-12. Wageningen: Wageningen Academic Publishers. https://doi.org/10.3920/978-90-8686-753-0_46

Green DD, McCann J (2011) Benchmarking a leadership model for the green economy. Benchmarking 18:445-465. https://doi.org/10. 1108/14635771111137804

Harvey DM, Bosco SM, Emanuele G (2010) The impact of "green collar workers" on organizations. Manag Res Rev 33:499-511. https://doi. org/10.1108/01409171011041929

Hassanli N, Walters T, Friedmann R (2020) Can cultural festivals function as counterspaces for migrants and refugees? The case of the new beginnings festival in Sydney. Leis Stud 39:165-180. https://doi. org/10.1080/02614367.2019.1666296

Hopkinson P, Zils M, Hawkins P, Roper S (2018) Managing a complex global circular economy business model: opportunities and challenges. Calif Manag Rev 60:71-94. https://doi.org/10.1177/ 0008125618764692

Horbach J, Rennings K, Sommerfeld K (2015) Circular Economy and employment. In 3rd IZA Workshop: Labor Market Effects of Environmental Policies, 1-39. Berlin: Centre for European Economic Research (ZEW). https://circulareconomy.europa.eu/ platform/sites/default/files/horbach j11332.pdf
Iacovidou E, Hahladakis JN, Purnell P (2021) A systems thinking approach to understanding the challenges of achieving the circular economy. Environ Sci Pollut Res 28:24785-24806

Ilić M, Šević NP, Bašić J, Ranković M (2020) Environmental protection and the circular economy; a new economic system for society and a business strategy - the case study of the Republic of Serbia. In: International Multidisciplinary Scientific GeoConference Surveying Geology and Mining Ecology Management, SGEM, 2020:235-240. https://doi.org/10.5593/sgem2020/5.2/s21.028

ILO (2020) Decent work. In: Decent work. https://www.ilo.org/global/ topics/decent-work/lang\%2D\%2Den/index.htm. Accessed 28 Dec 2020

ILO (2021) The green jobs initiative. https://www.ilo.org/beijing/whatwe-do/projects/WCMS_182418/lang\%2D\%2Den/index.htm. Accessed 15 May 2021

Karaferye F, Agaoglu E (2017) Perceptions of the dilemma-order versus freedom at managing faculty: a literature review. J Educ Pract 8: $122-132$

Kasztelan A (2016) Green competitiveness of the EU countries. In: Kovářová E, Melecký L, Staníčková M (eds) Proceedings of the 3rd International Conference on European Integration 2016. VŠB Technical University of Ostrava, Ostrava, pp 415-424

Kirchherr J, Reike D, Hekkert M (2017) Conceptualizing the circular economy: an analysis of 114 definitions. Resour Conserv Recycl 127:221-232. https://doi.org/10.1016/j.resconrec.2017.09.005

Korhonen J, Honkasalo A, Seppälä J (2018) Circular economy: the concept and its limitations. Ecol Econ 143:37-46. https://doi.org/10. 1016/j.ecolecon.2017.06.041

Ledoux L, Mertens R, Wolff P (2005) EU sustainable development indicators: an overview. Nat Resour Forum 29:392-403. https://doi.org/ 10.1111/j.1477-8947.2005.00149.x

Liu Z, Mei S, Guo Y (2020) Green human resource management, green organization identity and organizational citizenship behavior for the environment: the moderating effect of environmental values. Chin Manag Stud 15:290-304. https://doi.org/10.1108/CMS-10-20190366

Livesey D (2010) Measuring the environmental goods and services sector. Econ Labour Mark Rev 4:45-58. https://doi.org/10.1057/elmr. 2010.165

Lozano-Lunar A, Barbudo A, Fernández JM, Jiménez JR (2020) Promotion of circular economy: steelwork dusts as secondary raw material in conventional mortars. Environ Sci Pollut Res 27:89-100

Luca FA, Epuran G, Ciobanu CI, Horodnic AV (2019) Green jobs creation - main element in the implementation of bioeconomic mechanisms | Crearea de locuri de muncă ecologice - componentă de bază pentru implementarea mecanismelor bioeconomice. Amfiteatru Econ 21 (50): 60-74. https://doi.org/10.24818/EA/2019/50/60

McMahon K, Ryan-Fogarty Y, Fitzpatrick C (2021) Estimating job creation potential of compliant WEEE pre-treatment in Ireland. Resour Conserv Recycl 166. https://doi.org/10.1016/j.resconrec.2020. 105230,105230

Mehmet O (1995) Employment creation and green development strategy. Ecol Econ 15:11-19. https://doi.org/10.1016/0921-8009(95)000358

Moldvay J, Hamann R, Fay J (2013) Assessing opportunities and constraints related to different models for supplying wind turbines to the South African wind energy industry. Dev South Afr 30:315-331. https://doi.org/10.1080/0376835X.2013.817305

Moraga G, Huysveld S, Mathieux F, Blengini GA, Alaerts L, van Acker K, de Meester S, Dewulf J (2019) Circular economy indicators : what do they measure? Resour Conserv Recycl 146:452-461. https://doi.org/10.1016/j.resconrec.2019.03.045

Moreno-Mondéjar L, Triguero Á, Cuerva MC (2021) Exploring the association between circular economy strategies and green jobs in European companies. J Environ Manag 297:113437. https://doi. org/10.1016/j.jenvman.2021.113437 
Norgaard RB (1994) Development betrayed: the end of progress and a coevolutionary revisioning of the future. London - New York: Routledge

O'Connor G (2021) Shifting the value of food and organic waste management in the food services sector in Brisbane, Australia. Resour Conserv Recycl Adv 12:200052. https://doi.org/10.1016/j.rcradv. 2021.200052

Paes LAB, Bezerra BS, Deus RM, Jugend D, Battistelle RAG (2019) Organic solid waste management in a circular economy perspective - a systematic review and SWOT analysis. J Clean Prod 239: 118086. https://doi.org/10.1016/j.jclepro.2019.118086

Pearce D, Markandya A, Barbier EB (1989) Blueprint for a green economy. Earthscan, London

Pettinger L (2017) Green collar work: conceptualizing and exploring an emerging field of work. Sociol Compass 11:. doi: https://doi.org/10. $1111 /$ soc4.12443

Piwowar-Sulej K (2021) Human resources development as an element of sustainable HRM - with the focus on production engineers. J Clean Prod 278:124008. https://doi.org/10.1016/j.jclepro.2020.124008

Prieto-Sandoval V, Jaca C, Ormazabal M (2018) Towards a consensus on the circular economy. J Clean Prod 179:605-615. https://doi.org/10. 1016/j.jclepro.2017.12.224

Raszkowski A (2018) Towards sustainable development of territorial units - the case of revitalisation projects in Jelenia Góra Agglomeration municipalities. Econ Environ Stud 18:341-351. https://doi.org/10.25167/ees.2018.45.19

Rincón-Moreno J, Ormazabal M, Álvarez MJ, Jaca C (2020) Shortcomings of transforming a local circular economy system through industrial symbiosis: a case study in Spanish SMEs. Sustainability 12:. doi: https://doi.org/10.3390/su12208423

Robaina M, Villar J, Pereira ET (2020) The determinants for a circular economy in Europe. Environ Sci Pollut Res 27:12566-12578

Rojas Arboleda M, Pfeiffer A, Bezama A, Thrän D (2021) Anticipatory study for identifying the key influential factors of the biogas system in Germany contributing to the energy system of 2050. Futures 128: doi: https://doi.org/10.1016/j.futures.2021.102704, 102704

Ruiz-Real JL, Uribe-Toril J, Valenciano JDP, Gázquez-Abad JC (2018) Worldwide research on circular economy and environment: a bibliometric analysis. Int J Environ Res Public Health 15:. doi: https://doi.org/10.3390/ijerph15122699

Rutkowska-Podołowska M, Sulich A, Szczygieł N (2016) Green jobs. In: Kovářová E, Melecký L, Staníčková M (eds) Proceedings of the 3rd International Conference on European Integration 2016, ICEI 2016 : May 19-20, 2016, Ostrava, Czech Republic. Pt. 2. VŠB - Technical University of Ostrava, Ostrava, pp 822-829

Salvioni DM, Almici A (2020) Transitioning toward a circular economy: the impact of stakeholder engagement on sustainability culture. Sustainability 12:. doi: https://doi.org/10.3390/su12208641

Sanguino R, Barroso A, Fernández-Rodríguez S, Sánchez-Hernández MI (2020) Current trends in economy, sustainable development, and energy: a circular economy view. Environ Sci Pollut Res 27:1-7. https://doi.org/10.1007/s11356-019-07074-x

Sauvé S, Bernard S, Sloan P (2016) Environmental sciences, sustainable development and circular economy: alternative concepts for transdisciplinary research. Environ Dev 17:48-56. https://doi.org/10. 1016/j.envdev.2015.09.002

Schroeder P, Anggraeni K, Weber U (2019) The relevance of circular economy practices to the sustainable development goals. J Ind Ecol 23:77-95. https://doi.org/10.1111/jiec.12732

Sinclair-Desgagné B (2008) The environmental goods and services industry. Int Rev Environ Resour Econ 2:69-99. https://doi.org/10. 1561/101.00000012

Sołoducho-Pelc L, Sulich A (2020) Between sustainable and temporary competitive advantages in the unstable business environment. Sustain 12:. doi: https://doi.org/10.3390/su12218832
Song M, Xie Q (2019) How does green talent influence China's economic growth? Int J Manpow 41:1119-1134. https://doi.org/10.1108/ IJM-08-2019-0378

Song K, Kim H, Cha J, Lee T (2021) Matching and mismatching of green jobs: a big data analysis of job recruiting and searching. Sustain 13:. doi: https://doi.org/10.3390/su13074074

Steuer B, Broniewicz EE, Domańska W (2016) Environmental goods and services sector accounts. In: 9th International Scientific Conference "Business and Management 2016" At: Vilnius Gediminas Technical University, Lietuva. pp 17-30

Sugiyono, Dewancker BJ (2020) Study on the domestic water utilization in Kota Metro, Lampung Province, Indonesia: exploring opportunities to apply the circular economic concepts in the domestic water sector. Sustainability 12:. doi: https://doi.org/10.3390/su12218956

Sulich A (2018) The green economy development factors. In: Soliman KS (ed) Vision 2020: Sustainable economic development and application of innovation management from regional expansion to global growth. Proceedings of the 32nd International Business Information Management Association Conference (IBIMA). International Business Information Management Association (IBIMA), Prince of Prussia, pp 6861-6869

Sulich A, Zema T (2018) Green jobs, a new measure of public management and sustainable development. Eur J Environ Sci 8:69-75. https://doi.org/10.14712/23361964.2018.10

Sulich A, Rutkowska M, Popławski Ł (2020) Green jobs, definitional issues, and the employment of young people: an analysis of three European Union Countries. J Environ Manag 262:1-6. https://doi. org/10.1016/j.jenvman.2020.110314

Tang G, Chen Y, Jiang Y, Paillé P, Jia J (2018) Green human resource management practices: scale development and validity. Asia Pac J Hum Resour 56:31-55. https://doi.org/10.1111/1744-7941.12147

Toan PK, Cuong ND, Huong TTT (2016) Functional Characteristics of low carbon energy systems and need for Regional Cooperation in Vietnam. In: Investing on low-carbon energy systems. Springer Singapore, Singapore, pp 185-214

Tomić T, Schneider DR (2020) Circular economy in waste management -socio-economic effect of changes in waste management system structure. J Environ Manag 267:. doi: https://doi.org/10.1016/j. jenvman.2020.110564, 110564

Tortorella MM, Di Leo S, Cosmi C, et al (2020) A methodological integrated approach to analyse climate change effects in agri-food sector: the TIMES Water-Energy-Food Module. Int J Environ Res Public Health 17:. doi: https://doi.org/10.3390/ijerph17217703

Unay-Gailhard İ, Bojnec Š (2019) The impact of green economy measures on rural employment: green jobs in farms. J Clean Prod 208: 541-551. https://doi.org/10.1016/j.jclepro.2018.10.160

UNEP (2008) Green jobs: towards decent work in a sustainable, lowcarbon world

UNEP (2020) Green Jobs - UNEP Factsheet

United Nations (2021) Transforming our world: the 2030 agenda for sustainable development. In: Transform. our world 2030 Agenda Sustain. Dev. https://sdgs.un.org/2030agenda. Accessed 15 May 2021

van Dam K, Simeone L, Keskin D, Baldassarre B, Niero M, Morelli N (2020) Circular economy in industrial design research: a review. Sustain 12:1-19. https://doi.org/10.3390/su122410279

Vokoun M, Jílková J (2020)Eco-innovation activities in the czech economy 2008-2014: impact of the eco-innovative approach to the profit stream and differences in urban and rural enterprises. Economies 8:. doi: https://doi.org/10.3390/economies 8010003

Whitmarsh L, O’Neill S (2010) Green identity, green living? The role of pro-environmental self-identity in determining consistency across diverse pro-environmental behaviours. J Environ Psychol 30:305314 
Wilts H, Fecke M, Zeher C (2021) Economics of waste prevention: second-hand products in Germany. Economies 9:. doi: https://doi. org/10.3390/economies 9020074

Xu Q, Dhaundiyal S, Guan C (2020) Structural conflict under the new green dilemma: inequalities in development of renewable energy for emerging economies. J Environ Manag 273:111117. https://doi.org/ 10.1016/j.jenvman.2020.111117

Publisher's note Springer Nature remains neutral with regard to jurisdictional claims in published maps and institutional affiliations. 